\title{
The role of cardiac glycosides in influencing breast cancer cell proliferation
}

\author{
KD Quinlan*, MB Owens, ADK Hill, AM Hopkins \\ From International Conference for Healthcare and Medical Students 2011 \\ Dublin, Ireland. 4-5 November 2011
}

\begin{abstract}
Introduction
Cardiac Glycosides (CGs) are commonly used to treat congestive heart failure. CGs inhibit the Sodium Potassium ATPase $(\mathrm{Na}+\mathrm{K}+$ ATPase) pump. Interestingly, CGs have been suggested to inhibit proliferation and migration of breast cancer cells. A pool of non-pumping $\mathrm{Na}+/ \mathrm{K}+$ ATPase reportedly localizes in specific membrane organelles, caveolae, by interacting with the structural protein caveolin-1. It has been postulated that $\mathrm{Na}+/ \mathrm{K}+$ ATPase forms a complex with caveolin-1 and the tyrosine kinase $\mathrm{Src}$, and that binding of CGs to $\mathrm{Na}+/ \mathrm{K}+$ ATPase activates Src-dependent signalling cascades. In this project we explored whether CGs reduce proliferation in breast cancer cells and whether these effects might involve Src and ERK (Extracellular-signal-Regulated Kinases).
\end{abstract}

\section{Methods}

MDA-MB 231 cells [highly-invasive breast cancer cells] were transfected with siRNA to knock down caveolin-1 expression. MDA-MB-231 cells in which caveolin-1 was knocked down and MCF 10A cells (non-invasive breast cancer cells) were treated with CGs and subjected to MTT proliferation assays. MCF 7 cells (weakly-invasive breast cancer cells) were treated with the Src inhibitor PP2 in the presence or absence of CGs and analysed by western blotting for phosphorylated Src and phosphorylated ERK.

\section{Results}

High dose CGs (Digoxin>150nM, Ouabain>10nM, Oleandrin $>100 \mathrm{nM}$ ) reduced proliferation in MCF $10 \mathrm{~A}$ cells over 72 hrs. Caveolin-1 was successfully knocked-down in MDA-MB 231 cells, but this did not appear to abrogate the anti-proliferative effects of CGs. Early results suggest that phospho-Src and phospho-ERK expression were increased

Department of Surgery, Royal College of Surgeons in Ireland, Education \& Research Centre, Beaumont Hospital, Dublin, Ireland in MCF 7 cells treated with Digoxin. Interestingly, this was not abrogated by pre-treatment with the Src inhibitor PP2.

\section{Conclusions}

This project has demonstrated that CGs exert antiproliferative effects on a range of breast cancer cell lines. Early results suggest that the effects of CGs may not be directly linked to Src and ERK signalling. Ongoing work is determining whether caveolin-1 knockdown alters the anti-proliferative response to CG treatment. We suggest that further exploration of the mechanisms whereby CGs inhibit proliferation may reveal potential uses for CGs as anti-cancer drugs in the future.

Published: 9 July 2012

doi:10.1186/1753-6561-6-S4-P1

Cite this article as: Quinlan et al:: The role of cardiac glycosides in influencing breast cancer cell proliferation. BMC Proceedings 2012 6(Suppl 4):P1.

Submit your next manuscript to BioMed Central and take full advantage of:

- Convenient online submission

- Thorough peer review

- No space constraints or color figure charges

- Immediate publication on acceptance

- Inclusion in PubMed, CAS, Scopus and Google Scholar

- Research which is freely available for redistribution 